\title{
IMPAIRED SCOTOPIC VISION IN ADIPOSO-GENITAL DYSTROPHY*
}

IMPAIRMENT of dark adaptation was found frequently to occur in various endocrine disturbances of the genital function, and has been reported by us previously (Landau and Bromberg, 1950; Landau and Polishuk, 1948 ; Landau, Eckerling, and Polishuk, 1951; Landau and Bromberg, 1954). Disturbed scotopic vision was observed in the majority of patients suffering from pituitary or ovarian amenorrhea, in disorders of menopause and in oligospermia of central origin. Patients with tumours of the pituitary and diencephalic regions with endocrine dysfunction had distinctly disturbed dark adaptation. It was therefore suggested that the hypothalamus, which regulates various metabolic and gonadotropic functions, might conceivably play a role in the mechanism of scotopic vision.

This assumption led us to study scotopic vision in adiposo-genital dystrophy, a condition due to functional or organic disorders of the hypothalamus.

\section{Material and Methods}

Nineteen patients, thirteen females and six males, aged from 7-27, all suffering from adiposogenital dystrophy, were examined for dark adaptation. As it is difficult to differentiate between adiposo-genital dystrophy and primary gonadal failure or obesity with delayed sexual maturation, only those patients were considered by us as adiposo-genital dystrophy cases in whom the following clinical manifestations and laboratory findings were present:

(1) Adiposity involving particularly chin, neck, hips, and upper part of thighs;

(2) Poorly developed penis and testes in males, and atrophic uterus and vaginal mucosa with prolonged amenorrhea in females;

(3) Absence or under-development of secondary sex characteristics;

(4) Reduction of follicle-stimulating hormone in the urine.

In some patients, other hypothalamic disorders were found, as, for instance, diabetes insipidus, disorders of water metabolism, and insulin-resistant diabetes. In one patient of this series, bitemporal hemianopsia pointed to the diagnosis of a tumour in the mid-brain, which was confirmed at operation. Disturbances of diencephalic nature were found by electro-encephalography in many patients.

Six individuals, four females and two males, aged from 10 to 20 , suffering from obesity without genital or other endocrine disorders, were also examined for dark adaptation. In all these cases the distribution of body fat was not characteristic of adiposo-genital dystrophy.

Dark-adaptation tests were performed with Koch's adaptometer (Koch, 1945), a modification of Hecht's adaptometer, after a bleaching period of 5 minutes. In no case were pathological conditions of the eyes likely to impair dark adaptation. All the tests were carried out by the same examiner and under identical conditions.

\section{Results}

The final average rod threshold values found in healthy control subjects and reported in a previous study (Landau and Bromberg, 1950) were log. $3 \mu \mu$ Lamb. with a normal range between log. $2 \cdot 5 \mu \mu$ Lamb. and $3.6 \mu \mu$ Lamb. The final rod threshold values for dark adaptation found in patients suffering from adiposo-genital dystrophy are summarized in the Table (overleaf). 
TABLE

FINAL ROD THRESHOLD IN ADIPOSO-GENITAL DYSTROPHY

\begin{tabular}{|c|c|c|c|c|c|c|}
\hline $\begin{array}{l}\text { Case } \\
\text { No. }\end{array}$ & Sex & Age & Clinical Findings & $\begin{array}{c}\text { Abnormal Laboratory } \\
\text { Findings }\end{array}$ & $\begin{array}{l}\text { Log. } \mu \mu \\
\text { Lamb. }\end{array}$ & Remarks \\
\hline 1 & $F$ & 19 & $\begin{array}{l}\text { Pronounced obesity } \\
\text { Amenorrhea } \\
\text { Atrophic uterus } \\
\text { Diabetes } \\
\text { Oedema } \\
\text { Bitemporal hemianopia }\end{array}$ & $\begin{array}{l}\text { Low F.S.H. values } \\
\text { Hyperglycaemia } \\
\text { E.E.G.: disturbance of } \\
\text { diencephalic nature } \\
\text { Atrophic vaginal smear }\end{array}$ & $6 \cdot 4$ & $\begin{array}{l}\text { Tumour of dience- } \\
\text { phalic region, } \\
\text { confirmed at } \\
\text { operation }\end{array}$ \\
\hline 2 & $\mathrm{~F}$ & 17 & $\begin{array}{l}\text { Marked obesity } \\
\text { Primary amenorrhea } \\
\text { Stunted growth } \\
\text { Scanty pubic and axil- } \\
\text { lary hair } \\
\text { Atrophic uterus }\end{array}$ & $\begin{array}{l}\text { Low F.S.H. value } \\
\text { Atrophic vaginal smear } \\
\text { Atrophic endometrium }\end{array}$ & $4 \cdot 7$ & $\begin{array}{l}\text { Treated by low dos- } \\
\text { age roentgen irra- } \\
\text { diation of pitui- } \\
\text { tary and ovaries; } \\
\text { no effect }\end{array}$ \\
\hline 3 & $\mathrm{~F}$ & 15 & $\begin{array}{l}\text { Marked obesity } \\
\text { Stunted growth } \\
\text { Primary amenorrhea } \\
\text { Under - developed } \\
\text { secondary sex charac- } \\
\text { teristics }\end{array}$ & $\begin{array}{l}\text { Low F.S.H. values } \\
\text { Atrophic vaginal smear } \\
\text { Hypoglycaemia }\end{array}$ & $4 \cdot 6$ & \\
\hline 4 & $\mathrm{~F}$ & 16 & $\begin{array}{l}\text { Obesity } \\
\text { Primary amenorrhea } \\
\text { Under-developed geni- } \\
\text { talia and secondary } \\
\text { sex characteristics }\end{array}$ & $\begin{array}{l}\text { Low F.S.H. values } \\
\text { Atrophic vaginal smear } \\
\text { Small sella turcica }\end{array}$ & $4 \cdot 6$ & \\
\hline 5 & $\mathrm{~F}$ & 20 & $\begin{array}{l}\text { Pronounced obesity } \\
\text { Primary amenorrhea } \\
\text { No pubic and axillary } \\
\text { hair } \\
\text { Polyuria } \\
\text { Diabetes latens }\end{array}$ & $\begin{array}{l}\text { Low F.S.H. values } \\
\text { Atrophic endometrium } \\
\text { Atrophic vaginal smear } \\
\text { Decreased sugar toler- } \\
\text { ance } \\
\text { Small sella turcica }\end{array}$ & $5 \cdot 2$ & $\begin{array}{l}\text { Parents were first } \\
\text { cousins }\end{array}$ \\
\hline 6 & $\mathrm{~F}$ & 22 & $\begin{array}{l}\text { Marked obesity } \\
\text { Amenorrhea } 4 \text { years } \\
\text { Atrophic genitalia } \\
\text { Primary sterility } \\
\text { Headaches }\end{array}$ & $\begin{array}{l}\text { Low F.S.H. values } \\
\text { Atrophic uterine and } \\
\text { vaginal mucosa } \\
\text { E.E.G.: disturbance of } \\
\text { diencephalic nature }\end{array}$ & $6 \cdot 3$ & $\begin{array}{l}\text { Treated by oestro- } \\
\text { gens; withdrawal } \\
\text { bleeding; no } \\
\text { effect on dark } \\
\text { adaptation }\end{array}$ \\
\hline 7 & $\mathbf{F}$ & 25 & $\begin{array}{l}\text { Obesity } \\
\text { Amenorrhea } 6 \text { years } \\
\text { Atrophic uterus } \\
\text { Mental deficiency } \\
\text { Primary sterility }\end{array}$ & $\begin{array}{l}\text { Low F.S.H. values } \\
\text { Atrophic uterine and } \\
\text { vaginal mucosa } \\
\text { B.M.R. } 12 \text { per cent. } \\
17 \text { ketosteroids } 3 \mathrm{mg} . / \\
24 \text { hrs }\end{array}$ & $6 \cdot 6$ & $\begin{array}{l}\text { Subjected to insulin } \\
\text { shock therapy }\end{array}$ \\
\hline 8 & F & 22 & $\begin{array}{l}\text { Marked obesity } \\
\text { Amenorrhea } 3 \text { years } \\
\text { Stunted growth } \\
\text { Headaches } \\
\text { Primary sterility }\end{array}$ & $\begin{array}{l}\text { Low F.S.H. values } \\
\text { Atrophic uterine and } \\
\text { vaginal mucosa } \\
\text { Increased sugar toler- } \\
\text { ance } \\
\text { B.M.R. } 9 \text { per cent. } \\
\text { Small sella turcica }\end{array}$ & $7 \cdot 2$ & $\begin{array}{l}\text { Oestrogen and thy- } \\
\text { roid therapy; no } \\
\text { effect on dark } \\
\text { adaptation }\end{array}$ \\
\hline
\end{tabular}


TABLE-cont.

\begin{tabular}{|c|c|c|c|c|c|c|}
\hline $\begin{array}{l}\text { Case } \\
\text { No. }\end{array}$ & Sex & Age & Clinical Findings & $\begin{array}{l}\text { Abnormal Laboratory } \\
\text { Findings }\end{array}$ & $\begin{array}{l}\text { Log. } \mu \mu \\
\text { Lamb. }\end{array}$ & Remarks \\
\hline 9 & $\mathbf{F}$ & 22 & $\begin{array}{l}\text { Obesity } \\
\text { Amenorrhea } 4 \text { years } \\
\text { Headaches } \\
\text { Polyuria }\end{array}$ & $\begin{array}{l}\text { Low F.S.H. values } \\
17 \text { ketosteroid } 5 \mathrm{mg} \text {./ } \\
24 \text { hrs } \\
\text { B.M.R. } 6 \text { per cent. } \\
\text { Atrophic endometrium }\end{array}$ & $4 \cdot 6$ & $\begin{array}{l}\text { Treated by mare } \\
\text { serum and chor- } \\
\text { ionic gonadotro- } \\
\text { pins; no effect }\end{array}$ \\
\hline 10 & $\mathbf{F}$ & 14 & $\begin{array}{l}\text { Very marked obesity } \\
\text { No secondary sex } \\
\text { characteristics }\end{array}$ & $\begin{array}{l}\text { Low F.S.H. values } \\
\text { Small sella turcica }\end{array}$ & 6.9 & $\begin{array}{l}\text { Parents related; } \\
\text { mother suffering } \\
\text { from diabetes } \\
\text { Mental retardation }\end{array}$ \\
\hline 11 & $\mathbf{F}$ & 22 & $\begin{array}{l}\text { Obesity } \\
\text { Amenorrhea } 4 \text { years } \\
\text { Atrophic uterus } \\
\text { Primary sterility }\end{array}$ & $\begin{array}{l}\text { Low F.S.H. values } \\
\text { Atrophic uterine and } \\
\text { vaginal mucosa } \\
\text { Glucosuria }\end{array}$ & $4 \cdot 6$ & $\begin{array}{l}\text { Treated by oestro- } \\
\text { gens and proges- } \\
\text { terone; no effect } \\
\text { Mental retardation }\end{array}$ \\
\hline 12 & $\mathbf{F}$ & 23 & $\begin{array}{l}\text { Obesity } \\
\text { Amenorrhea } 3 \text { years } \\
\text { Headaches } \\
\text { Primary sterility }\end{array}$ & $\begin{array}{l}\text { Low F.S.H. values } \\
\text { B.M.R. } 17 \text { per cent. } \\
\text { E.C.G.: suggesting di- } \\
\text { encephalic disturbance } \\
\text { Hyperglycaemia } \\
\text { Atrophic endometrium }\end{array}$ & $4 \cdot 7$ & $\begin{array}{l}\text { Treated by oestro- } \\
\text { gens and proges- } \\
\text { terone; no effect }\end{array}$ \\
\hline 13 & $\mathbf{F}$ & 27 & $\begin{array}{l}\text { Obesity } \\
\text { Amenorrhea } 9 \text { years } \\
\text { Atrophic genitalia } \\
\text { Primary sterility } \\
\text { Diabetes }\end{array}$ & $\begin{array}{l}\text { Low F.S.H. values } \\
\text { Hyperglycaemia } \\
\text { Atrophic endometrium } \\
\text { E.E.G.: suggesting dien- } \\
\text { cephalic disturbances }\end{array}$ & $5 \cdot 8$ & $\begin{array}{l}\text { Treated by low dos- } \\
\text { age roentgen irra- } \\
\text { diation; no effect }\end{array}$ \\
\hline 14 & $\mathbf{M}$ & 14 & $\begin{array}{l}\text { Obesity } \\
\text { Very small penis } \\
\text { Bilateral cryptorchismus }\end{array}$ & $\begin{array}{l}\text { Low F.S.H. values } \\
17 \text { ketosteroid } 3 \mathrm{mg} . / \\
24 \text { hrs }\end{array}$ & $5 \cdot 7$ & $\begin{array}{l}\text { Parents related } \\
\text { Treated by chor- } \\
\text { ionic gonadotro- } \\
\text { pin; no effect }\end{array}$ \\
\hline 15 & $\mathbf{M}$ & $13 \frac{1}{2}$ & $\begin{array}{l}\text { Obesity } \\
\text { Stunted growth } \\
\text { Small penis and testes } \\
\text { No axillary and pubic } \\
\text { hair }\end{array}$ & $\begin{array}{l}\text { Low F.S.H. values } \\
\text { B.M.R. } 16 \text { per cent. } \\
\text { Small sella turcica }\end{array}$ & $5 \cdot 6$ & $\begin{array}{l}\text { Suffered from ence- } \\
\text { phalitis } 8 \text { years } \\
\text { previously } \\
\text { Mental retardation }\end{array}$ \\
\hline 16 & $\mathbf{M}$ & $8 \frac{1}{2}$ & $\begin{array}{l}\text { Obesity } \\
\text { Small penis } \\
\text { Bilateral cryptorchismus }\end{array}$ & $\begin{array}{l}\text { Small sella turcica } \\
\text { Decreased sugar toler- } \\
\text { ance }\end{array}$ & $6 \cdot 6$ & \\
\hline 17 & $\mathbf{M}$ & $6 \frac{1}{2}$ & $\begin{array}{l}\text { Obesity } \\
\text { Small penis and testes }\end{array}$ & Small sella turcica & $5 \cdot 5$ & Brother of Case 16 \\
\hline 18 & $\mathbf{M}$ & 12 & $\begin{array}{l}\text { Obesity } \\
\text { Stunted growth } \\
\text { Small penis } \\
\text { Bilateral cryptorchismus } \\
\text { No pubic and axillary } \\
\text { hair }\end{array}$ & $\begin{array}{l}\text { Low F.S.H. values } \\
\text { B.M.R. } 24 \text { per cent. }\end{array}$ & $5 \cdot 7$ & $\begin{array}{l}\text { Encephalitis } 6 \text { years } \\
\text { previously } \\
\text { Epilepsy }\end{array}$ \\
\hline 19 & $\mathbf{M}$ & 14 & $\begin{array}{l}\text { Obesity } \\
\text { Stunted growth } \\
\text { Small penis and testes } \\
\text { Scanty pubic and } \\
\text { axillary hair }\end{array}$ & $\begin{array}{l}\text { Low F.S.H. values } \\
17 \mathrm{ketosteroids} 2 \mathrm{mg} . / \\
24 \mathrm{hrs} \\
\text { E.E.G.: suggesting dien- } \\
\text { cephalic disturbances }\end{array}$ & $4 \cdot 6$ & \\
\hline
\end{tabular}


The Table shows clearly that all those patients examined who were suffering from adiposo-genital dystrophy had disturbed scotopic vision. The final rod threshold values varied from log. $4 \cdot 6 \mu \mu$ Lamb. to log. $7 \cdot 2 \mu \mu$ Lamb. (mean log. 5.57 $\mu \mu$ Lamb.). The six cases of obesity without evident endocrine disorders showed normal rod threshold values.

\section{Discussion}

Impairment of dark adaptation, found by us to occur in various endocrine disorders of the genital function, seems not to be related to any of the generally known and accepted factors of disturbed scotopic vision, as reviewed by Duke-Elder (1942).

As those conditions were related to interference with hypothalamic, pituitary, and ovarian functions, it seemed probable that impaired dark adaptation observed in these disorders may also be connected with the same regulating mechanism. The failure to improve impairment of dark adaptation by substitutive gonadal hormone therapy (oestrogen, progesterone, testosterone) led us to assume that disturbed scotopic vision is related rather to a dysfunction of higher centres in the pituitary or hypothalamus, regulating the hormonal activity of the gonads.

In gonadal failure secondary to pituitary deficiency in both women and men, the scotopic vision was very frequently, but not constantly, disturbed. On the other hand, a constant and distinct impairment of dark adaptation was found in all cases of adiposo-genital dystrophy.

There is a consensus of opinion that this disease is induced by organic or functional disorders of the hypothalamus (Taubenhaus and Oberhill, 1950; Soffer, 1951). The role of the hypothalamus in the regulation of fat metabolism in animals has been experimentally demonstrated by Crowe, Cushing, and Homans (1910), and by Camus and Roussy (1913). Hetherington and Ranson $(1939,1942)$ confirmed these findings by exact experimental technique, producing obesity by lesions in various locations within the hypothalamus. Genital dystrophy associated with adiposity was experimentally produced in various animals by injury to the hypothalamus without affecting the hypophysis (Smith, 1927; Grafe and Groenthal, 1919). In men, adiposo-genital dystrophy was observed in organic lesions of the mid-brain, such as tumours and inflammatory processes (Kraus, 1945; Soffer, 1951). It was also claimed that this condition may be due to a functional disturbance without any evident organic lesion in the pituitary hypothalamic region (Rony, 1940). The constant occurrence of impaired dark adaptation in all cases of adiposo-genital dystrophy studied seems to point to the possibility that the mechanism of scotopic vision may be dependent upon the hypothalamic function. The fact that all six cases of obesity without evident endocrine disorders showed normal dark adaptation seems also to support this opinion. Impaired dark adaptation may thus be of value in differential diagnosis of adiposo-genital dystrophy and in cases of obesity of other aetiology. 


\section{Summary}

Nineteen patients suffering from adiposo-genital dystrophy were examined for dark adaptation.

Impairment of dark adaptation was found in all cases.

In obese individuals without endocrine disorders, normal dark adaptation values were found.

The finding of impaired dark adaptation may be of diagnostic value in differentiating adiposo-genital dystrophy from other forms of obesity.

It is suggested that the mechanism of scotopic vision may be related to the function of the hypothalamus.

\section{REFERENCES}

Camus, J., and Roussy, G. (1913). C. R. Soc. Biol. (Paris), 75, 483.

Crowe, S. J., Cushing, H., and Homans, J. (1910). Johns Hopk. Hosp. Bull., 21, 127.

Duke-Elder, S. (1938). "Text-book of Ophthalmology", vol. 1, p. 982. Kimpton, London.

Grafe, E., and Grünthal, E. (1929). Klin. Wschr., 8, 1013.

Hetherington, A. W., and Ranson, S. W. (1939). Proc. Soc. exp. Biol. (N.Y.), 41, 465. (1942). Endocrinology, 31, 30.

Kraus, J. E. (1945). Arch. Path. (Chicago), 40, 191.

LANDAU, J., and BromberG, Y. M. (1950). "XVI Concil. Ophthal., 1950, Britannia Acta", p. 574.

- , (1954). Amer. J. Ophthal. (in press).

- ECKerling, B., and PolishuK, Z. (1951). Harefuah, 41, 195.

, and PolishuK, Z. (1948). Acta med. orient. (Tel Aviv), 7, 153.

RoNY, H. R. (1940). "Obesity and Leanness", p. 48. Lea and Febiger, Philadelphia.

SMith. P. E. (1927). J. Amer. med. Ass., 88, 158.

SOFFER, L. G. (1951). "Diseases of the Endocrine Glands", p. 152. Lea and Febiger, Philadelphia.

Taubenhaus, M., and Oberhill, H. R. (1950). " Progress in Clinical Endocrinology", ed. S. Soskin, p. 469. Grune and Stratton, New York. 